\section{Dignidade e respeito aos pacientes: 0 olhar dos Direitos Humanos}

Fabiano Maluf

Universidade de Brasília, Departamento de Saúde

Coletiva, Brasília, Distrito Federal, Brasil.

$<$ maluffabiano@gmail.com>

http://dx.doi.org/10.1590/1981-7746-sol00133

AlbuQUerque, Aline. Direitos Humanos dos Pacientes. Curitiba: Juruá Editora, 2016, 288 p.

Em tempos de judicialização da saúde, o livro Direitos humanos dos pacientes, de Aline Albuquerque, apresenta extenso arcabouço teórico dos direitos humanos e agrega importantes elementos à promoção e à defesa dos direitos dos pacientes. A obra tem como objetivo principal conjugar os conceitos dos direitos humanos ao âmbito dos cuidados em saúde dos pacientes tendo como base a normativa internacional sobre a temática.

O livro é dividido em três partes. A primeira, Aspectos gerais dos direitos humanos dos pacientes, é composta por dois capítulos. No primeiro capítulo, observa-se o cuidado em delimitar os conceitos de direitos humanos e de paciente. Parte da premissa de que os direitos humanos existem para concretizar a dignidade humana, de modo que todos os seres humanos, sem nenhuma distinção, possam desenvolver suas capacidades pessoais.

Aborda também o Sistema de Direitos Humanos da Organização das Nações Unidas, o Sistema Interamericano de Direitos Humanos, sistemas aos quais se vincula o Estado brasileiro; e inclui o Sistema Europeu de Direitos Humanos por possuir este vasta jurisprudência no campo dos direitos humanos demarcando, dessa forma, as obrigações legais dos Estados contidas nesses três sistemas.

Define a tipologia obrigacional na qual os Estados têm as seguintes obrigações de direitos humanos: obrigações de respeitar, de proteger e de realizar - razão pela qual a falha em cumprir uma dessas obrigações acarreta séria violação dos direitos humanos.

Com relação à conceituação de 'paciente', deixa claro que o termo carrega dupla condição de vulnerabilidade e de centralidade no processo terapêutico - e acolhe seu uso por ser utilizado pelos movimentos reivindicatórios dos direitos humanos; pela condição de vulnerabilidade expressada pelo termo e pela relação humana existente nos cuidados em saúde em detrimento aos termos 'usuários' e 'consumidores'.

O segundo capítulo trata da teoria e dos princípios dos direitos humanos dos pacientes. Faz um resgate do panorama dos movimentos, organizações de pacientes e legislações acerca dos direitos dos pacientes, iniciando-se pelos Estados Unidos, passando pela Europa até chegar ao Brasil.

Destaca, ainda, a distinção entre o referencial dos Direitos Humanos dos Pacientes e as normas de direitos dos pacientes que, a despeito de se entrelaçarem, não são semelhantes. Os Direitos Humanos dos Pacientes derivam da dignidade humana inerente a todo ser humano, previstos em normas jurídicas de caráter vinculante, já as normas de direitos dos pacientes centram-se na perspectiva individualista do paciente sob bases consumeristas, dispostas em declarações, sem qualquer obrigatoriedade jurídica. Ressalta que o reconhecimento dos Direitos Humanos dos Profissionais de Saúde reverbera em benefício dos pacientes e contribui para disseminação de uma cultura de direitos humanos nos ambientes de cuidados em saúde.

Apresenta os pontos de convergência entre a Bioética e os Direitos Humanos dos Pacientes, porém reitera que ambos referenciais se expressam por meio de distintas linguagens e objetivos diferenciados, "a Bioética tem o escopo de refletir e prescrever moralmente, e o dos Direitos Humanos dos Pacientes, o de estabelecer obrigações juridicamente vinculantes aos atores governamentais com vistas à proteção dos pacientes" (p. 68). Evidencia os pontos de distanciamentos dos referenciais da Humanização da Atenção à Saúde notadamente em função da linguagem empregada, de cunho moral e motivacional, e do não reconhecimento do papel intransferível das autoridades estatais em prover condições dignas de cuidados em saúde para pacientes e de trabalho para os profissionais de saúde.

Nesse sentido, a obra traz à tona a discussão sobre a Abordagem Baseada nos Direitos Humanos aplicada à saúde ter como foco políticas e programas de saúde distantes da perspectiva do paciente. Assim, propõe uma inflexão no campo da 
bioética com o intuito de adotar uma perspectiva inclusiva, que recusa uma acepção atomista do indivíduo, ou seja, defende um conteúdo mínimo basilar do princípio da dignidade humana: “o de que cada ser humano possui um valor intrínseco que deve ser respeitado" (p. 77).

Albuquerque finaliza o capítulo abordando os princípios dos Direitos Humanos dos Pacientes: o Princípio do Cuidado Centrado no Paciente, notadamente o direito ao respeito pela vida privada e o direito à informação; o Princípio da Dignidade Humana que, apesar de polissêmico e complexo, assinala o papel fundamental para sua materialização na esfera dos cuidados em saúde dos pacientes; o Princípio da Autonomia Relacional, que enfatiza a interdependência do paciente com o meio relacional que o circunda, e o Princípio da Responsabilidade dos Pacientes, que corrobora que ao compartilhar informações e concorrer para a construção de seu plano terapêutico, o paciente reparte a responsabilidade pelo tratamento escolhido.

A segunda parte do livro, denominada "O conteúdo dos Direitos Humanos dos Pacientes", compreende nove capítulos nos quais são tratados em profundidade os conteúdos de sete direitos humanos dos pacientes (do capítulo 3 ao 9): direito à vida; direito a não ser submetido à tortura, nem a penas ou tratamentos cruéis, desumanos ou degradantes; direito à liberdade e segurança pessoal; direito ao respeito à vida privada; direito à informação; direito de não ser discriminado; e direito à saúde, todos detalhados posteriormente à apresentação da metodologia de levantamento e de desenvolvimento da jurisprudência internacional adotada (capítulos 1 e 2).

A abordagem dos direitos delimita-se a três aspectos: uma apresentação do assunto para melhor situar o leitor; as principais conexões entre o tema e o direito em análise e a exposição de casos ou relatórios sobre o tema. Busca-se extrair de cada direito humano outros, mais específicos, destinados a serem aplicados na esfera dos cuidados em saúde. O que se tem como maior contribuição do capítulo é a demonstração que “determinados direitos comumente atribuídos aos pacientes derivam de normas de direitos humanos e que a jurisprudência internacional em matéria de direitos humanos vem aplicando dispositivos de tal natureza com vistas a proteger o paciente" (p. 180).

A parte 3, intitulada "Aplicação dos direitos humanos dos pacientes", defende a importância da figura do Agente do Paciente em seus diferentes contextos e condições específicas; ressalta a experiência normativa do Reino Unido, notadamente o sistema mais avançado em termos de direitos humanos dos pacientes e apresenta as normas brasileiras sobre os direitos dos pacientes sob a perspectiva dos direitos humanos, guardando especial atenção às legislações existentes em seis estados brasileiros.

Encerra o capítulo apresentando as justificativas para uma proposta de lei brasileira sobre os direitos dos pacientes sob a perspectiva dos direitos humanos, devido ao fato de não existirem políticas governamentais voltadas para a concretização de tais direitos e do vazio legislativo que concorre para a propagação de ações violadoras dos direitos humanos dos pacientes.

Nesse sentido, é oportuno ressaltar o Projeto de Lei no 5559/16, em tramitação na Câmara dos Deputados, ao considerar que é dever do Estado zelar pela proteção das pessoas na condição de pacientes, adotar legislação condizente com sua situação específica de vulnerabilidade e que prevê os direitos dos pacientes com base nos documentos internacionais de direitos humanos e de bioética (SOCIEDADE BRASILEIRA DE BIOÉTICA, 2017).

De modo geral, percebe-se que injustiças e tratamentos desumanos podem ocorrer mais frequentemente em localidades onde não se reconhecem os direitos humanos dos pacientes no discurso político e em legislações. Assim, é de fundamental importância a necessidade de se ter direitos que assegurem a oportunidade e a segurança de persegui-los e reivindicá-los.

De fácil leitura e compreensão, a obra convida os leitores a uma reflexão crítica ao lançar luz sobre a temática, incipiente no país, e contribuir para fortalecer, no Brasil, uma nova perspectiva, a da cultura dos direitos dos pacientes no âmbito dos cuidados em saúde. Desse modo, ser possuidor de direitos numa sociedade que assegura a vigência e a concretização dos direitos humanos dos pacientes é ao mesmo tempo uma fonte de proteção pessoal e uma fonte de respeito à dignidade humana. 


\section{Referência}

SOCIEDADE BRASILEIRA DE BIOÉTICA. Carta de Recife. Moção de apoio ao Projeto de Lei $n^{\circ}$ 5559/16 - Estatuto dos Direitos do Paciente. XII Congresso Brasileiro de Bioética. VI Congresso de Bioética Clínica. Recife, 28 de setembro de 2017. Disponível em: <http://www.sbbioetica.org.br/uploads/repositorio/2017_11_01/CARTA-DE-RECIFE.pdf $>$. Acesso em: 16 de março de 2018. 